\title{
Wind energy in South Africa: A review of policies, institutions and programmes
}

\author{
Chipo Mukonza ${ }^{1^{*}}$, Godwell Nhamo $^{2}$ \\ Institute of Corporate Citizenship, University of South Africa, P O Box 392, Unisa 0003, South Africa
}

\begin{abstract}
South Africa is promoting renewable energy such as wind power to address the objectives of both energy security and sustainable development. This paper reviews the nature of policies, institutional set-up and programmes in place to upscale especially onshore wind energy uptake, as reflected in publicly available documents. It shows that South Africa has put in place critical policies, institutions and programmes for wind energy uptake. Among key policy documents and policies are the White Paper on Energy (1998), Renewable Energy White Paper (2003), Energy Act of 2008, and National Climate Change Response White Paper (2011). There is also the Integrated Energy Plan, the Integrated Resource Plan (2010, revised 2013) and Environmental Impact Assessment Guidelines for Renewable Energy Projects of 2015. Key institutions noted include the South African National Energy Development Institute, the South African Renewable Energy Council and the South African Wind Energy Association. The main programme is the
\end{abstract}

Renewable Energy Independent Power Producers Procurement Programme, which resulted in more than 30 installed wind energy projects. Overall, wind energy promises to be among the viable and acceptable technologies in the renewable energy sector in South Africa.

Keywords: renewable energy; initiatives; stakeholders

Journal of Energy in Southern Africa 29(2): 21-28

DOI: http://dx.doi.org/10.17159/2413-3051/2018/v29i2a1433

Published by the Energy Research Centre, University of Cape Town ISSN: 2413-3051 http://journals.assaf.org.za/jesa

Sponsored by the Department of Science and Technology

\footnotetext{
* Corresponding author: Tel: +27 12433 4656;

email: chiponyam@gmail.com
} 


\section{Introduction}

The need to diversify the energy mix has necessitated the development and deployment of renewable energy sources and technologies globally. Wind energy is one such source, which can be harvested through wind turbines and windmills (Khare et al., 2013; Sholapurkar and Mahajan, 2015). According to the Renewable Energy Policy Network for the 21st Century (REN21), more than 90 countries witnessed commercial wind activity by December 2016, with 29 of these each having more than one gigawatt (GW) in operation (REN21, 2017). As of 2014, wind energy technology has generated an estimated 800000 jobs (Small, 2014), which were attributed to the formulation and implementation of progressive and proactive policies and programmes, as well as new institutions. In addition, major technological advances on the global market have been observed since 2005 (Walwyn and Brent, 2015), especially developments in turbine designs, which resulted in increased height of towers, length of blades, and overall wind turbine power capacity (Department of Trade and Industry (DTI), 2015).

In Southern Africa, it is expected that between $11800 \mathrm{MW}$ and $12500 \mathrm{MW}$ of wind energy projects could be deployed by 2030 (REN21, 2015) and South Africa remains a major player. The country stands to benefit by transitioning to a green economy (Nhamo, 2013), owing to its abundance of natural energy resources, especially solar and wind. There are, however, challenges that need to be addressed if South Africa is to reach its full potential in exploiting these resources; among these are policies, institutions and programmes aimed at helping to upscale wind energy. Greenpeace (2013) found that the government's Renewable Energy Independent Power Producer Procurement Programme (REI4P) was restricted to $9 \%$ renewable energy in the energy mix by 2030 , which focuses more on security of supply than access to power. In addressing the question of what was holding South Africa's renewable energy programme back, Greenpeace addressed the following main issues: continued strong lobbying for fossil and nuclear power and entrenched political interests; local government revenue structures that depend heavily on reselling energy; subsidised coal and nuclear power; administrative bottlenecks, limited research and development; grid capabilities; and perceptions on renewable energy capacity.

This report aims to provide an audit of policies, programmes and institutions promoting wind energy upscaling in South Africa. The twin objectives of the study behind it were: (1) to identify policies that have been put in place to support and upscale wind energy uptake in South Africa; and (2) to document and examine programmes and institutions that have been put in place for such uptake. Section 2 discusses literature review, and Section 3 introduces the methodology. Section 4 presents results and discussion, and Section 5 offers conclusions and suggests policy implications for future growth of wind energy in South Africa.

\section{Literature survey: The development of wind energy and technologies}

Wind energy has attracted considerable academic attention (including Small, 2016; Ejdemo, 2015; Global World Energy Council - GWEC, 2016). Small (2016) indicated an exponential growth in wind energy, primarily because of the decreasing costs of production and global pressure to reduce greenhouse gas emissions in order to mitigate climate change. Estimated global installed wind capacity was 432419 MW by the end of 2015 (GWEC, 2016); the trend is illustrated in Figure 1.

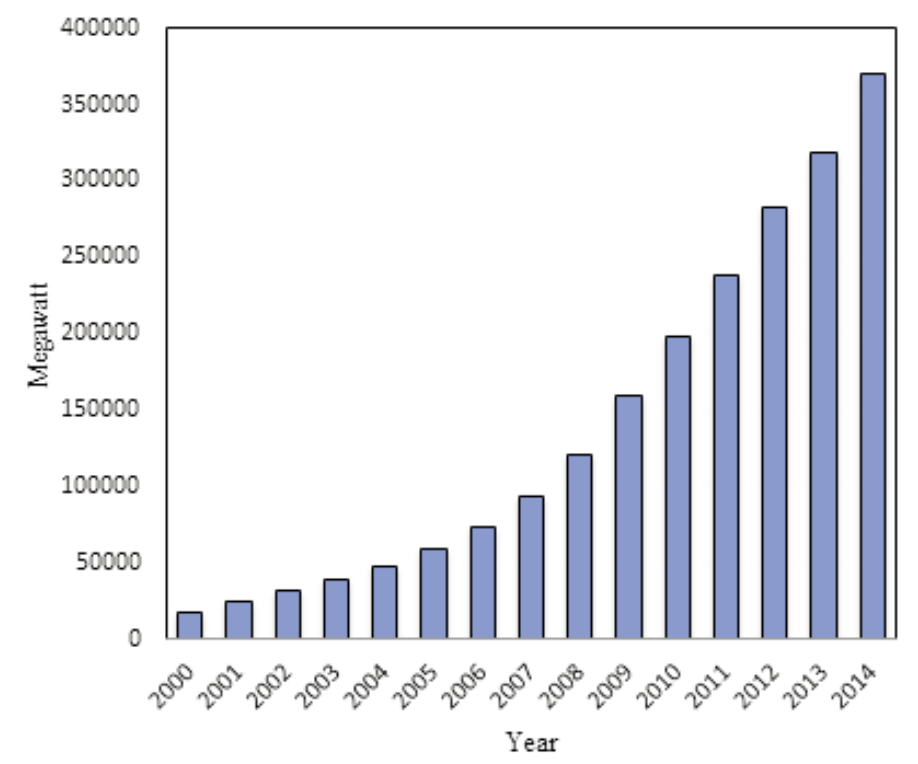
Figure 1: Trends in global installed wind capacity, 2000-2014
(Authors, based on GWEC, 2016).

The benefits of wind energy include diversification of a country's energy supply mix; spurring innovation, job creation (as shown in Table 1) and economic development; reduction in the use of fossil fuels; reduction in environmental damage; and less exposure to the price volatility of renewable energy. In South Africa wind energy is exploited from onshore facilities. Table 1 shows that by 2015 China had the largest wind energy installations, 145 362 MW, corresponding to approximately 280000 jobs. United States of America is in second place with $8598 \mathrm{MW}$, while Germany recorded about 6 013 MW, with an estimated 150000 jobs. Six countries dominated installed capacity in 2015, namely China, USA, Germany, Spain, India and the United Kingdom.

The implementation of strong policies and legislative measures have resulted in uptake of wind 
Table 1: Wind energy developments and jobs created up to 2015 in selected countries (GWEC, 2016)

\begin{tabular}{lccccc}
\hline Country & $\begin{array}{c}\text { Wind capacity added } \\
\text { 014-2015 (MW) }\end{array}$ & $\begin{array}{c}\text { Total installed } \\
\text { capacity (MW) }\end{array}$ & $\begin{array}{c}\text { Number of } \\
\text { turbines }\end{array}$ & $\begin{array}{c}\text { Electricity demand } \\
\text { covered by wind } \\
\text { power (\%) }\end{array}$ & $\begin{array}{c}\text { Number of people } \\
\text { employed by the } \\
\text { wind industry }\end{array}$ \\
\hline Australia & 380 & 4187 & 2062 & 5.00 & 200 \\
Brazil & 2750 & 8720 & 4360 & 3.50 & 41000 \\
Canada & 1506 & 11205 & 6066 & 5.00 & $73000^{*}$ \\
China & 30753 & 145362 & 92981 & 3.32 & 280000 \\
Egypt & 200 & 810 & 800 & 1.00 & 250 \\
India & 2623 & 25085 & 1750 & & 48000 \\
Netherlands & $586 \mathrm{~W}$ & 3431 & 2174 & 5.60 & 150 \\
Uruguay & 316 & 845 & 614 & 19.5 & 500 \\
United States & 8598 & 74471 & 48500 & 4.70 & 3000 \\
United Kingdom & 975 & 13603 & 6680 & 11.0 & 150000 \\
Germany & 6013 & 44947 & 26774 & 12.0 & 5000 \\
Japan & 245 & 3038 & 2077 & 0.50 & \\
\hline
\end{tabular}

* only in Ontario, Canada

energy. In the USA, for example, fiscal incentives and new regulations were introduced, allowing retail electricity customers to procure wind energy and other alternative sources of energy (Liao, 2016; Black et al., 2014). A study to assess the regulatory framework in the European Union showed a trend to increase wind generators, feed-in premiums and competitive bidding to establish wind development (Gonzalez and Lacal-Arantegui, 2016).

China has slowly amended its wind energy policies since 1995 to promote the development of this energy source (Liao, 2016), with ten policies focusing on wind energy released in 2005 alone. It also published a new statute, Regulating the wind manufacturing market (Decree 412), in September 2014, the new regulations incorporating extracts from earlier regulations and giving further details on their implementation. This way, there is an element of continuity in policy, which is an important aspect for the growth of the industry and for investor confidence. The new regulations emphasises quality control and introduces a compulsory certification process (Liao, 2016), with all main turbine parts and components requiring certification before they can be cited in tenders.

In India, since 1983 the use of wind energy has been rising, with the commissioning of the wind programme (Khare et al., 2013). India effected a generation-based incentive scheme for grid-connected wind power projects in 2009 . It aimed to enable the entry of large independent power producers and provide a level playing field for various classes of investors. In addition the government launched the National Wind Energy Mission, which was intended to fast-track the development of wind energy projects and open avenues for offshore production (GWEC, 2015). Further, the wind policy released in February 2015 proposed a target of 60
GW cumulative installed capacity of onshore wind power by 2020 (GWEC, 2016).

As early as 1979, Japan established its Moonlight Program, aimed at advancing energy-saving technology (Mizuno, 2014). The following year, the New Energy and Industrial Technology Development Organisation was created to manage social research leading to the development of new energy, conservation technologies and the creation of a new market for them. The financial support resulted in Japan establishing a wind resource database. A field testing and data-gathering project was established between 1995 and 2006, and a local area wind energy prediction system developed between 1999 and 2002 (Mizuno, 2014). To date, three technology roadmaps have been done - for 2007, 2008 and 2009 (GWEC, 2016). Japan implemented an energy innovation program for wind in three phases: 2008-2012, 2008-2014 and 2007-2011(GWEC, 2016). Such progression guaranteed harmonious transition.

According to Cheng (2011) and Liao (2016, the literature presents three main taxonomies of wind energy policy: environmental, supply, and demand, as shown in Table 2. Environmental types of wind energy policy are premised on government efforts to influence the wind energy industry via tax systems, laws, regulation and other such instruments. (The USA is a good example of a country that has implemented such polices.) Supply types of wind energy policy are based on governments seeking to improve energy supply, increasing market output, and supporting the development of wind energy through making important information, technology and finance available (Cheng, 2011). The aim is to remove barriers to market entry, reduce market risks and trade control (Liao, 2016). When undertaking a critical review of policies that were developed to 
Table 2: The classification of wind energy policies (Cheng, 2011; Liao, 2016)

\begin{tabular}{|c|c|c|}
\hline Policy type & Instrument name & Definition \\
\hline \multirow[t]{4}{*}{ Environmental } & Goal-planning & $\begin{array}{l}\text { Demand for clean energy determines development of wind energy. The } \\
\text { national government will then enact policies to achieve it. }\end{array}$ \\
\hline & Financial support & $\begin{array}{l}\text { Government avails financial incentives for the development of wind } \\
\text { energy and relaxes some of the restrictions that would have been imposed. }\end{array}$ \\
\hline & Tax preference & $\begin{array}{l}\text { Tax reductions are given to enterprises, researchers and production } \\
\text { companies in the industry and these are extended to consumers. }\end{array}$ \\
\hline & Regulation control & $\begin{array}{l}\text { For a fair and orderly competitive environment, the government establishes } \\
\text { laws and regulations. }\end{array}$ \\
\hline \multirow[t]{3}{*}{ Supply } & $\begin{array}{l}\text { Technology infor- } \\
\text { mation support }\end{array}$ & $\begin{array}{l}\text { Development of wind energy requires setting up information databases and } \\
\text { government providing scientific and technological support. }\end{array}$ \\
\hline & $\begin{array}{l}\text { Infrastructure } \\
\text { construction }\end{array}$ & $\begin{array}{l}\text { Environment favouring establishment of research and development } \\
\text { laboratories. }\end{array}$ \\
\hline & Capital investment & $\begin{array}{l}\text { Financial resources provided at various stages of wind development value } \\
\text { chain by government. }\end{array}$ \\
\hline \multirow[t]{3}{*}{ Demand } & $\begin{array}{l}\text { Government } \\
\text { procurement }\end{array}$ & Purchasing wind power equipment and the energy produced by wind. \\
\hline & Outsourcing & $\begin{array}{l}\text { The government entrusts research and development plans to corporate or } \\
\text { private research institutions to promote wind energy R\&D. }\end{array}$ \\
\hline & Trade control & $\begin{array}{l}\text { Government creates enabling environment for investment and trade } \\
\text { opportunities. }\end{array}$ \\
\hline
\end{tabular}

support wind energy, it is imperative that one assesses and analyse the type of policies crafted by the country (Cheng, 2011).

\section{Methodology}

The present study was carried out using meta-analysis and content analysis of publicly available information and data, including the Wind Atlas for South Africa, publications, policy documents and industry-specific information, of both South African and international origin. Content analysis allowed for the examination of trends and patterns in wind energy development. In addition, the study employed meta-analysis to present data relating to wind capacity installed, jobs created and impact of wind energy on prices. The data sets were drawn from Department of Energy reports, newspaper articles, industry-specific publications, and company reports, according to the methodology outlined by Barnett-Page and Thomas (2009).

\section{Results and discussion}

\subsection{Regulatory and institutional framework}

The study established that several policies provided entry points for the development of wind energy, including the White Paper on the Energy Policy 1998, White Paper on Renewable Energy 2003, Integrated Energy Plan 2003 and the Integrated Resource Plan (IRP) 2010. Table 3 presents a summary of some important policies in South Africa to promote renewable energy, including wind.

Table 3 shows that South Africa introduced renewable energy policy frameworks, anticipating a need to increase electricity generation from wind (Musango and Brent, 2015). On 26 November
2016 an updated IRP draft plan was released for public hearing, with the view to have it finalised in March 2017. The updated version estimated an additional $37400 \mathrm{MW}$ of power from wind by 2050 (van Rooyene, 2016). However, the quest to upscale renewble energy, including wind, met some uncertainities as Eskom, the national power utility company with a mandate to supply electiricity, refused to enter into power purchase agreements with preferred bidders arising from government's REI4P (South African Wind Energy Association, 2016a).

The wind localisation study suggests that there is a need for stricter measures to encourage local content, local manufacturing and local job creation with minimal increases in capital expenditure for projects (Department of Trade and Industry, 2015). The bid evaluation criteria for the REI4P demands that $70 \%$ should be related to price and the remaining $30 \%$ to economic, job creation, local content, ownership management, and preferential procurement consideration. Table 4 highlights benefits towards economic development of onshore wind projects.

South Africa has several institutions that promote renewable energy, including: the Department of Energy (DoE), Energy Development Corporation, South African National Energy Development Institute, South African Wind Energy Association, South African Renewable Energy Council, South African Renewables Initiative and Sustainable Energy Society Southern Africa. The DoE is the custodian policy formulation, implementation and coordination, in corporation with the Department of Trade and Industry (DTI), which launched the WINDABA (which is an event for Wind Energy 
Table 3: Summary of the regulatory frameworks and guidelines (DoE, 2015; DEA, 2015)

\begin{tabular}{ll}
\hline \multicolumn{1}{c}{ Policy } & \multicolumn{1}{c}{ Description } \\
$\begin{array}{l}\text { White Paper on Energy } \\
\text { Policy (1998) }\end{array}$ & $\begin{array}{l}\text { The first policy document related to energy development in the post-apartheid era. } \\
\text { The main objective was to address energy access. South Africa had to position itself } \\
\text { as a country which strives to meet the supply and demand of energy needs by } 2010 .\end{array}$ \\
$\begin{array}{l}\text { Renewable Energy White } \\
\text { Paper (2003) }\end{array}$ & $\begin{array}{l}\text { The policy provided a target for renewable energy deployment indicating that } \\
\text { The 2008 Energy Act }\end{array}$ \\
$\begin{array}{l}\text { The Act stipulated the diversification of energy sources ensuring that the prices are } \\
\text { affordable to ordinary people and produced in a sustainable manner. }\end{array}$ \\
$\begin{array}{ll}\text { National Response to South } \\
\text { Africa's Electricity Shortage }\end{array}$ & $\begin{array}{l}\text { The intention was to establish the country's electricity distribution structure, and } \\
\text { production of electricity by independent power producers. }\end{array}$
\end{tabular}
(2008)

UNFCCC $15^{\text {th }}$ Session of COP15 commitment to cut emissions (Zuma, 2009)

Integrated Energy Plan (2003) Integrated Resource Plan (2010)

Integrated Resource Plan 2010 -2030 update (2013)

Green Economy Accord (2011)

Industrial Action Plan 2014/15-2016/17

National Development Plan Vision 2030 (2012)

Commitment to diversify and take mitigation action to reduce emissions by $34 \%$ by 2020 and $42 \%$ by 2025 below 'business as usual' in South Africa. This commitment carried through into the 2012 National Development Plan whose vison goes to 2030 .

Specified energy supply trade-offs done on a project-by-project basis.

Aimed to reduce GHG emission and excite innovation, to create employment opportunities. Set a target of $17.8 \mathrm{GW}$ of renewable energy, of which 8.4 GW should be from wind. The IRP is supposed to be revised every two years.

The updated version revised down the target for renewable energy from

$17800 \mathrm{MW}$ to $10000 \mathrm{MW}$ in line with the economic outlook, which considered a shift away from energy-intensive industries. Of the $10000 \mathrm{MW}, 4360 \mathrm{MW}$ to come from wind energy.

Committed to procure 3725 MW of renewable energy for the national grid by 2016 and create at least 50000 green jobs by 2020 .

Emphasis on component manufacture and promotion of black economic empowerment in renewable energy projects.

Called for an increase in electricity generation reserve margin from $1 \%$ (2014) to $19 \%$ by 2019 , requiring the development of $10 \mathrm{GW}$ of additional electricity capacity by 2019 against the 2010 baseline of $44 \mathrm{GW}$, with $5 \mathrm{GW}$ of the $10 \mathrm{GW}$ to be sourced from renewable energy.

Wind Energy Industrial Allowed for the phasing in of wind energy in South Africa.

Strategy for South Africa (2014)

International Energy Agency Provide guidance on the environmental management legal framework applicable to Guideline for Renewable Energy Projects (2015) renewable energy operations and all the role players in the sector. It identified activities requiring environmental authorisation prior to the commencement of such activities, including wind farms.

Table 4: Benefits of economic development from onshore wind (Department of Energy, (2015)

\begin{tabular}{lcccc}
\hline Parameter & Bid window 4 & Bid window 3 & Bid window 2 & Bid window 1 \\
\hline MW allocation & 676 & 787 & 563 & 634 \\
Local content value (million rand) & 5146 & 6283 & 4817 & 2727 \\
Local content (\%) & 44.6 & 46.9 & 48.15 & 27.4 \\
Job creation: Construction (citizens) & 2831 & 2612 & 1787 & 1810 \\
Job creation: Operations (citizens) & 8161 & 8506 & 2238 & 2461 \\
\hline
\end{tabular}

stakeholders active on the African continent) in 2014. The main mandate of DTI is in localisation of goods and services with the aim to broaden participation in the economy to strengthen economic development (DTI, 2015). In addition, there is the Department of Environmental Affairs that is responsible for environment authorisation and environmental impact assessments of wind energy projects.

\subsection{Programmes on wind energy}

In 2010, the DoE, the National Treasury and the
Development Bank of Southern Africa set up the Indpendent Power Producer (IPP) Office and designed the REI4P (DoE, 2015a), which was introduced after the renewable energy feed-in tariff failed to be rolled out in 2009 because of lack of market demand (International Renewable Energy Agency, 2013). The REI4P provided a clearer framework upon which Eskom could enter into power purchase agreements with producers. The aim was to ensure that investors could accurately forecast their profits and bankability. To date, four 
successful wind energy bidding rounds have taken place under the REI4P. As of December 2017, there were 22 full operational onshore wind farms feeding 1 876.6 MW into the national electricity grid (Kretzmann, 2017). Overall, there were 92 projects that have qualified in the four bidding rounds, with 34 of them projected to contribute about $2660 \mathrm{MW}$ (DoE, 2015a).

What emerges from the wind energy bidding rounds is that $\mathrm{kWh}$ prices fell with each bidding window. Figure 2 shows that the last and fourth bidding round averaged $\mathrm{R} 0.71 \mathrm{c} / \mathrm{kWh}$, a decline of $100 \%$ compared with the first bidding round of R1.42/ $\mathrm{kWh}$. Other raw figures show that Round 2's price dropped to $\mathrm{R} 1.12 / \mathrm{kWh}$ from $\mathrm{R} 1.42 / \mathrm{kWh}$, while Round 3 pricing was $\mathrm{R} 0.82 / \mathrm{kWh}$. The introduction of renewable energy into the national grid resulted in a reduction of an equivalent of 4.4 million tonnes of carbon dioxide emission (CSIR, 2015). Wind energy produced net savings of ZAR 1.8 billion in the first half of 2015 and was also cash-positive for Eskom by ZAR 300 million (CSIR, 2015).

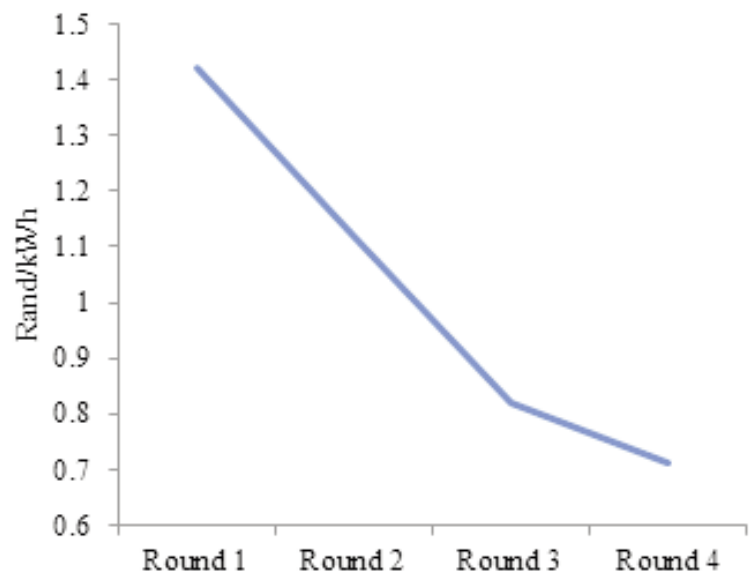

Figure 2: Price per kWh in the wind energy bidding rounds (2012-2015).

Figure 3 shows the REI4P success rate. With each successive bidding window, there has been a downward pressure regarding the number of qualifying projects. Round 1 had 53 bidders and only 23 qualified, a success rate of about $52 \%$. Round 2 had 79 bidders and 19 qualified, a 24\% success rate. Round 3 had 93 bidders, of which 17 qualified, an $18 \%$ success rate. Round 4 had 77 bids and 13 qualified, a $16.8 \%$ success rate. The number of qualifying projects can only confirm the market interest, supply capacity, and the potential of renewable energy that can be produced.

Regardless of the successes witnessed in renewable energy in general and wind energy specifically, there seems to have been negative sentiments from other stakeholders in the country. When the Department of Energy announced its intention to conclude outstanding 27 contracts for the REI4P for bidding window 3 and 4 on 13 March 2018, labour and other civil society organisations took the Minister to court. The contestations were related to potential labour loss from scaling down on fossil fuel-based energy like coal and the new opportunities likely to be created by the new REI4P projects (Radebe, 2018a). The contractual obligations from the government's side on bidding windows 3 and 4 have been delayed for about three years. The aggrieved parties that took the matter to court on 12 March 2018 on an urgent basis were Transform RSA NPC and the National Union of Metal Workers of South Africa. On 29 March 2018, High Court Judge Dawie Fourie ruled in favour of the government, indicating that the matter was not urgent and it was accordingly struck from the roll with costs to Transform RSA NPC and the National Union of Metal Workers of South Africa (Ibid.). A list of selected wind projects from bidding window 4 is shown in Table 5.

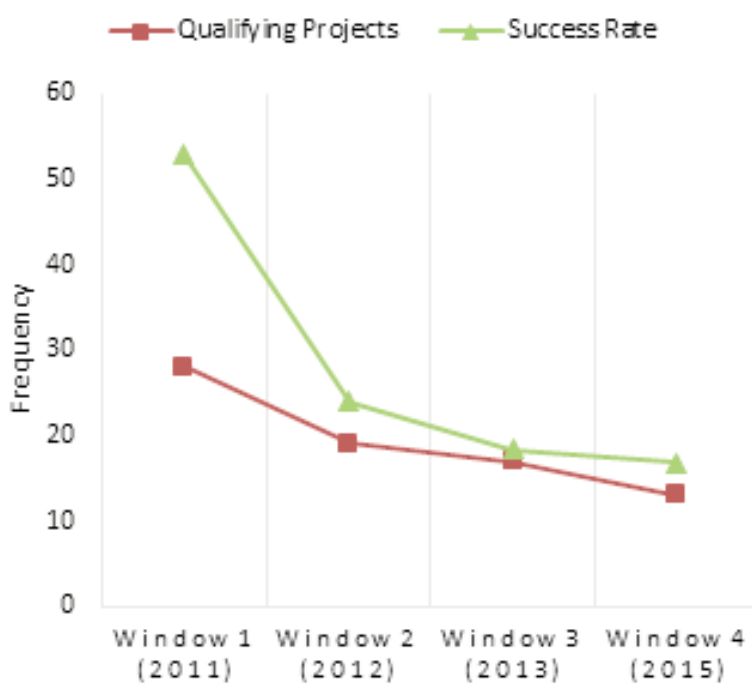

Figure 3: Renewable Energy Independent Power Producer Procurement bidder success rate, 2011-2015.

Table 5: Summary of selected onshore wind projects from bidding window 4 (based on IPP Projects (2018).

\begin{tabular}{lc}
\hline Project name & Contracted capacity (MW) \\
\hline Copperton Windfarm & 102.00 \\
Excelsior Wind Energy Facility & 31.90 \\
Garob Wind Farm & 135.93 \\
Golden Valley Wind & 117.72 \\
Kangnas & 136.70 \\
Oyster Bay Wind Farm & 140.00 \\
Perdekraal East & 107.76 \\
Roggeveld Wind Farm & 140.00 \\
The Karusa Wind Farm & 139.80 \\
The Nxuba Wind Farm & 138.90 \\
The Soetwater Wind Farm & 139.40 \\
Wesley-Ciskei & 32.70 \\
\hline
\end{tabular}


Following the High Court ruling, the Minister of Energy concluded the 27 REI4P projects with a 20year life span. In his own words upon concluding the contracts, the Minister 'could not hide his excitement', especially that his former portfolio had dealt with implementing the National Development Plan - Vision 2030, which emphasised the need to reduce unemployment, poverty and inequality in South Africa. Minister Radebe indicated that the government had:

reached this milestone following a long period of uncertainty, not only for the renewable energy industry, but also for private sector investment in the energy sector as a whole. This has not been good for investor confidence in our country neither for the management of the economy. The procurement of the 27 new projects is the biggest IPP procurement by the Department of Energy to date, representing a total of R56 billions of investment and about 2 $300 \mathrm{MW}$ of generation capacity to be added to the grid over the next 5 years. (Radebe, 2018b)

The arguments from labour were controversial, as the 27 REI4P projects are expected to create an estimated 61600 full-time new jobs. The bulk of them would emerge from the construction phases of the projects, in which South Africans companies have a $57.8 \%$ share. Not only are there South African shareholders, but an average of $64.2 \%$ of the $57.8 \%$ stake is for previously disadvantaged black South Africans (Radebe, 2018). The 27 projects committed to further employ black South Africans in $86 \%$ of top management positions. The projects will also focus on education and skills development, social welfare, healthcare, general administration and enterprise development. Another bidding window has been promised for $1800 \mathrm{MW}$ of renewable energy with a potential to create 80000 more jobs. However, this promise will depend on affordability (pricing, economics and value for money). From the current projects, the wind projects would demand 500 wind towers and turbines, which the local economy will benefit from.

\section{Conclusions}

-In South Africa, four policies have been instrumental in the deployment of wind energy: the White Paper on Renewable Energy, the National Energy Act, the Integrated Energy Plan, and Integrated Resource Plan. South Africa's Renewable Energy Independent Power Producers Procurement Programme led to the introduction of more than 30 wind projects, marking a breakthrough for the supply side for clean energy. An emerging challenge is contestation from other stakeholders, especially organised labour, which feels that jobs associated with conventional sources of energy like coal, and associated value chains, are threatened by renewable energy sources. Countries promoting wind energy use preferential policies that mainly come in three categories: environmental, supply, and demand. The primary aims of South African policies have been to accelerate progress, open new markets, and create demand, while promoting a cleaner environment. Further research should look at wind energy development under different market conditions.

\section{References}

Barnett-Page, E. and Thomas, J. 2009. Methods for the synthesis of qualitative research: A critical review. ESRC National Centre for Research Methods. London

Black, G., Holley, D., Solan, D. and Bergloff, M. 2014. Fiscal and economic impacts of state incentives for wind energy development in the Western United Sates. Renewable and Sustainable Energy Reviews 34: 136-144 https://doi.org/10.1016/j.rser.2014.03.015

Cheng, X. T. 2011. Content analysis of wind power policy in China - based on government instrument [Master Degree thesis]. Department of Administrative Management, Zhejiang University.

Council for Scientific and Industrial Research. 2015. Financial costs and benefits of renewable energy in South Africa in 2014. Available online: http://www.csir.co.za/docs/Financial\%20benefits\%20 of\%20Wind\%20and\%20PV\%20in\%202014\%20CSIR\%20-\%2021Jan2014_FINAL.pdf [Accessed 17 February 2016].

Department of Energy. 2016. State of Renewable Energy in South Africa. Available online: http://www.gov.za/sites/www.gov.za/files/State\%20of \%20Renewable\%20Energy\%20in\%20South\%20Afri ca_s.pdf [Accessed 15/15/2016]

Department of Environmental Affairs. 2015. EIA Guideline for Renewable Energy Projects. Department of Environmental Affairs, Pretoria, South Africa.

Department of Trade and Industry. 2015. The wind energy industry localisation roadmap in support of large-scale roll-out in South Africa. Integrated final report. Available online: http://www.wasaproject. info/docs/WindEnergyLocalisationStudyJan2015.pdf [Accessed 16 February 2016].

Ejdemo, T. and Soderholm, P. 2015. Wind power, regional development and benefit-sharing: The case of Northern Sweden. Renewable and Sustainable Energy Reviews 47: 476-485. https://doi.org/10.1016/j.rser.2015.03.082

Greenpeace. 2013. Powering the future: Renewable energy roll-out in South Africa. Johannesburg: Greenpeace.

GWEC (Global Wind Energy Council). 2016. Global wind statistics, 2015. Available online: http://www.gwec.net/wp-content/uploads/vip/GWECPRstats-2015_LR.pdf [Accessed 27 November 2016].

GWEC (Global Wind Energy Council). 2016. Indian 
Wind Energy: A brief outlook. Available online: www.gwec.net/wp-content/uploads/vip/ GWEC_IWEO_2016_LR.pdf [Accessed 14 May 2018].

Gonzalez, J.S. and Lacal-Arantegui, R. 2016. A review of regulatory framework for wind energy in European Union countries: Current state and expected Developments. Renewable and Sustainable Energy Reviews 56: 588-602. https://doi.org/10.1016/j.rser.2015.11.091

International Renewable Energy Agency. 2013. Renewable energy auctions in developing countries. Available online: https://www.irena.org/ DocumentDownloads/Publications/IRENA_Renewabl e_energy_auctions_in_developing_countries.pdf [Äccessed 31 May 2016].

Independent Power Projects-IPP. 2018. Renewable IPPPP - Bid Window 4 Preferred Bidders. Pretoria: IPP Projects.

Khare, V., Nema, S. and Baredar, P. 2013. Status of solar, wind renewable energy in India. Renewable and Sustainable Energy Reviews 27: 1-10. https://doi.org/10.1016/j.rser.2013.06.018

Kretzmann, S. 2017. Wind farms can be deadly December 12, 2017. News24. Available online: https:/www.fin24.com/Economy/wind-farms-can-bedeadly-20171217-2 [Accessed 13 May 2018].

Liao, Z. 2016. The evolution of wind energy policies in China (1995-2014): An analysis based on policy instruments. Renewable and sustainable Energy Reviews 56: 464-472. https://doi.org/10.1016/j.rser.2015.11.097

Mizuno, E. 2014. Overview of wind energy policy and development in Japan. Renewable and Sustainable Energy Reviews 40: 999-1018. https://doi.org/10.1016/j.rser.2014.07.184

Musango, J.K., Brent. A.C. and Tshangela. M. 2014. Green economy transitioning of the South African power sector: A system dynamics analysis approach. Development Southern Africa 31(5): 744-758. DOI: 10.1080/0376835X.2014.930792. https://doi.org/10.1080/0376835X.2014.930792

New Energy Update. 2016. International investment in the South African renewable energy market. With CSP Today, PV Insider and Wind Energy Update South Africa. Available online: http://www.pv-insider.com/cms-assets/documents/232822-341102.international-investment-design-2.pdf [Accessed 15 January 2016].

Nhamo G. 2013. Green economy readiness in South Africa: A focus on the national sphere of government. International Journal of African Renaissance Multi and Transdisciplinary 8 (1): 115-142. https://doi.org/10.1080/18186874.2013.834628

Radebe, 2018a. Media statement: Minister of Energy, Hon Jeff Radebe welcomes the High Court Ruling in the application to interdict the signing of the Power Purchase Agreements for the 27 Independent Power Producer Projects 29th March 2018. Pretoria: Department of Energy.

Radebe, J. 2018b. Speech by the Minister of Energy, Hon Jeff Radebe, MP at the Renewable Energy Independent Power Producer Programme (REIPPPP) Bid Windows 3.5 and 4 Contractual
Close signing ceremony 4 April 2018. Pretoria: Department of Energy.

Renewable Energy Policy Network for the 21st century. 2015. Renewables 2015. Global Status Report. Key findings 2015. London.

Sholapurkar, R. B. and Mahajan.Y. S. 2015. Review of wind energy development and policy in India. Energy Technology \& Policy 2: 122-132. https://doi.org/10.1080/23317000.2015.1101627

Small, L. 2014. Fact sheet: Jobs in renewable energy and efficiency. December 23, 2014. EESI.

Washington. Available online: http://www.eesi.org/ papers/view/fact-sheet-jobs-in-renewable-energyand-energy-efficiency-2014 [Accessed on 18 August 2015].

Small, L. 2016. Offshore wind: Can the United States catch up with Europe? Fact Sheet. January 2016. EESI. Washington. Available online: http://www.eesi.org/papers/view/factsheet-offshorewind-2016 [Accessed on 17 March 2016].

South African Wind Energy Association. 2016a. South Africa harnesses power of the wind. Available online: http://www.southafrica.info/about/sustainable/wind-energy-290216.htm\#.V02xcP196Uk [Accessed 27 May 2016].

Stemler, S. 2007. An overview of content analysis, practical assessment. Research and Evaluation. Available online: http://pareonline.net/getvn.asp? $\mathrm{v}=7 \& \mathrm{n}=17$ [Accessed 19 February 2016].

Van Rooyen, M. 2016. Back to the energy drawing board. 25 Degrees in Africa newsletter.

Walwyn, D.R. and Brent, A. C. 2015. Renewable energy gathers steam in South Africa. Renewable and Sustainable Energy Reviews 41: 390-401. https://doi.org/10.1016/j.rser.2014.08.049

Zuma, J. 2009. Message by South African President Jacob Zuma to the UN Secretary General's High Level Summit on Climate Change. Pretoria. 